\title{
Defective Early Phase Insulin Release in Perifused Isolated Pancreatic Islets of Spiny Mice (Acomys Cahirinus)*
}

\author{
A. Rabinovitch, A. Gutzeit, M. Kikuchi, E. Cerasi and A. E. Renold \\ Institute of Clinical Biochemistry, Dept. of Medicine, Univ. of Geneva, Geneva, Switzerland \\ Received: March 17, 1975, and in revised form: July 3, 1975
}

\begin{abstract}
Summary. In order to characterize pancreatic beta cell function in Geneva bred spiny mice (acomys cahirinus), the dynamics of immunoreactive insulin release were examined during perifusion of pancreatic islets isolated from normoglycemic acomys. The initial insulin response of acomys was slow: no clear-cut early ( 1 to $10 \mathrm{~min})$ peak of insulin release was observed when glucose in the perifusion medium was abruptly raised from $2.8 \mathrm{mM}$ to concentrations as high as $56 \mathrm{mM}$. This was true for islets of either young, or older more obese acomys. However, after 20 to $30 \mathrm{~min}$ of perifusion at the high glucose concentrations, the rate of insulin release from acomysislets became similar to that from islets of rats or mice. By contrast, glucose-induced insulin release responses observed with islets of Wistar-derived rats, Swiss albino mice, and inbred C57 BL/6J lean or obese $(o b / o b)$ mice, were clearly biphasic. Tolbutamide $1.5 \mathrm{mM}$, arginine $16 \mathrm{mM}$, and theophylline $10 \mathrm{mM}$ were ineffective in stimulating insulin release from acomys islets in the presence of a
\end{abstract}

Previous studies of the spiny mice (acomys cahirinus) in our colony have established that the acomys species is one of several among small rodents that may develop a diabetes-like syndrome of spontaneous inappropriate hyperglycemia and obesity $[1,2,3]$, at least under certain conditions and when bred in the laboratory. Furthermore, low insulin secretory responses in vivo (by comparison with mice and rats) have been demonstrated even in normoglycemic acomys $[4,5]$, in spite of the considerable hyperplasia of the pancreatic islets of Langerhans and the increased insulin stores characteristic of this species [1, 2]. Our aim in the present experiments was to characterize the insulin secretory response of acomys more directly, using isolated pancreatic islets in vitro, the comparison being again with rats and mice. Since a

* This work was presented in part at the Third Brook Lodge Workshop on Spontaneous Diabetes in Laboratory Animals, Augusta, Michigan, May, 1974, and at the Meeting of the Israel Societies of Diabetes and Endocrinology, Jerusalem, September, 1974.

Dr. Rabinovitch is a Centennial Fellow of the Medical Research Council of Canada.

Dr. Cerasi is a Visiting Professor at the University of Geneva, on sabbatical leave from the Department of Endocrinology and Metabolism, Karolinska Hospital, Stockholm, Sweden. In 1973 he received a Pfizer-Europe Travel Fellowship through the European Association for the Study of Diabetes. substimulatory glucose concentration $(2.8 \mathrm{mM})$, whereas these agents were effective in rat islets at the same substimulatory concentration of glucose. On the other hand, when these agents, as well as cyclic AMP $10 \mathrm{mM}$ or cytochalasin B $10 \mu \mathrm{g} / \mathrm{ml}$ were applied in the presence of a stimulating concentration of glucose $(16.8 \mathrm{mM})$, the glucose-stimulated insulin release from acomys islets was increased to the same or to a greater extent than from rat islets. It is suggested that the failure of all the agents tested to stimulate an early rapid phase of insulin release from acomys islets may be secondary to the observed initial insensitivity to glucose, which insensitivity may in turn reflect a selective impairment in the recognition of glucose as an insulinogenic signal in this species.

Key words: Insulin secretion, perifused islets, spiny mouse (acomys cahirinus), obese (ob/ob) $\mathrm{C} 57 \mathrm{BL} / 6 \mathrm{~J}$ mice, glucose, tolbutamide, arginine, theophylline, cyclic AMP, cytochalasin B.

number of studies have indicated that the dynamics of insulin release are modified in the diabetic syndrome in man [6-11], and in other species [12], an experimental procedure that allowed for analysis of insulin release kinetics, i.e. islet perifusion, was selected.

\section{Material and Methods}

\section{Animals}

The characteristics of the acomys cahirinus, rats, and mice used in this study are shown in Table 1. Acomys, of both sexes, were obtained from the colony bred in our laboratory, as were the Swiss albino mice, and Wistar-derived rats. Male obese (ob/ob) C57 $\mathrm{BL} / 6 \mathrm{~J}$ mice and their appropriate lean controls were purchased from the Jackson Laboratories, Bar Harbour, Maine, at the age of 6 weeks, and used at 20 weeks of age.

Islets were obtained from all animals in the fed state, between 9 and $10 \mathrm{am}$. Insulin responses from islets of young acomys (8-14 weeks) were compared to those from rat and albino mouse islets, whose insulin contents were similar to that of the young 
Table 1. Characteristics of acomys cahirinus, rats and mice used in this study

\begin{tabular}{|c|c|c|c|c|}
\hline Species and strain & Age & Body weight & Plasma Glucose $^{a}$ & Islet insulin content $t^{b}$ \\
\hline & (wks) & $(\mathrm{g})$ & $(\mathrm{mg} / 100 \mathrm{ml})$ & (ng/islet) \\
\hline Acomys cahirinus & $8-14$ & $25-40$ & $145 \pm 7(12)$ & $19.8 \pm 2.5(23)$ \\
\hline Acomys cahirinus & $22-36$ & $60-90$ & $181 \pm 12$ & $36.3 \pm 4.8$ \\
\hline Wistar-derived rats & $6-12$ & $150-200$ & $129 \pm 8$ (6) & $21.3 \pm 2.0(21)$ \\
\hline Swiss albino mice & $8-14$ & $25-35$ & $157 \pm 11$ & $18.8 \pm 2.8(15)$ \\
\hline Lean $+/+$ C57BL $/ 6 \mathrm{~J}$ mice & 20 & $24-27$ & $158 \pm 11$ & $19.5 \pm 3.5$ \\
\hline Obese $o b / o b$ C57BL/6J mice & 20 & $42-46$ & $224 \pm 14$ & $92.8 \pm 8.0$ \\
\hline
\end{tabular}

acomys. Also, the mean ( \pm SEM) plasma glucose concentration of the young acomys $(145 \pm 7 \mathrm{mg} / 100$ $\mathrm{ml}$ ) was intermediate between that of the rats and albino mice, and not significantly different from either. The older acomys (22-36 weeks) were more obese $(60-90 \mathrm{~g})$, and exhibited a significantly elevated mean $( \pm$ SEM) plasma glucose concentration (181 \pm $12 \mathrm{mg} / 100 \mathrm{ml}, p<0.02$ ), and approximately double the islet insulin content compared to young acomys. Insulin responses from islets of these older, more obese acomys were compared to those from islets of these obese $(o b / o b)$ C57 BL/6J mice, who exhibited still greater elevations of plasma glucose and islet insulin content.

\section{Experimental Procedures}

Pancreatic islets of Langerhans were isolated from the different rodents by a modification of the collagenase (Worthington Chemical Corp., Freehold, N. J.) method of Lacy and Kostianovsky [13]. Pancreatic digestion (at $37^{\circ} \mathrm{C}$ ) and subsequent isolation of the islets (at $4^{\circ} \mathrm{C}$ ) was carried out in Hank's solution containing glucose $2.8 \mathrm{mM}$ and gassed with $95 \%$ $\mathrm{O}_{2}: 5 \% \mathrm{CO}_{2}$ (pH 7.4). After digestion (4 to $6 \mathrm{~min}$, with $7 \mathrm{mg}$ collagenase per $\mathrm{ml}$ ), the pancreatic sediment was centrifuged and washed four times, again with centrifugation, then transferred to a blackbottomed Petri dish. By visualization through a binocular dissecting microscope, and using a $10 \mu \mathrm{l}$ micropipette, the islets were then further separated from any surrounding exocrine tissue by three successive isolations and transfers into Petri dishes containing fresh Hank's solution. For each perifusion experiment, the islets used could be obtained from a single acomys pancreas, or from pancreases pooled from 2 rats, 4 albino mice, $4 \mathrm{C} 57 \mathrm{BL} / 6 \mathrm{~J}$ lean mice, or 1 $o b / o b$ mouse. In each instance, 40 islets were transferred into each of six individual perifusion chambers.
The perifusion system as applied to fragments of whole pancreas in this laboratory, has been described in considerable detail [14]. The basic medium was Krebs-Ringer bicarbonate buffer ( $\mathrm{pH}$ 7.4), continuously gassed with $95 \% \mathrm{O}_{2}: 5 \% \mathrm{CO}_{2}$, and containing bovine albumin $5 \mathrm{mg} / \mathrm{ml}$ (Fraction V, Behringwerke, Marburg, Germany) as well as glucose $2.8 \mathrm{mM}$. The buffer reservoirs and islet chambers were maintained at $37^{\circ} \mathrm{C}$. Perifusion of islets, at a constant flow rate of 2.5 to $3.0 \mathrm{ml} / \mathrm{min}$ was begun between 40 and $60 \mathrm{~min}$ after sacrifice of the animals.

For all perifusions, an initial $20 \mathrm{~min}$ equilibration period with glucose $2.8 \mathrm{mM}$ preceded the stimulation period, which lasted $30 \mathrm{~min}$; this was followed by return to glucose $2.8 \mathrm{mM}$ for $10 \mathrm{~min}$. In the first set of experiments, the glucose dose-response studies were performed using glucose $2.8 ; 5.6,8.4,16.8$, or $56 \mathrm{mM}$ in the stimulation buffer. In the second set, tolbutamide Na 1.5 mM (Farbwerke Hoechst A.G., Frankfurt/Main-Hoechst, Germany), arginine hydrochloride $16 \mathrm{mM}$, theophylline $10 \mathrm{mM}$, cyclic AMP $10 \mathrm{mM}$ (Sigma Chemical Co., St. Louis, Mo.), or cytochalasin B $10 \mu \mathrm{g} / \mathrm{ml}$ (Imperial Chem. Industries, Macclesfield, U.K.) was added to the stimulation buffer containing glucose at one of 3 concentrations: $2.8,8.4$ or $16.8 \mathrm{mM}$. Control perifusions in the absence of non-glucose stimulating agents, but at each corresponding glucose concentration, were always performed on islets obtained from the same collagenase isolation batch. For the experiments with cytochalasin $B$, the agent was also present during the $20 \mathrm{~min}$ pre-stimulation period with glucose $2.8 \mathrm{mM}$, and control experiments with glucose $16.8 \mathrm{mM}$ alone were performed in the presence of dimethylsulfoxide $10 \mu \mathrm{l} / \mathrm{ml}$ (Fluka A. G., Buchs, Switzerland), the vehicle used to dissolve cytochalasin B.

The effluent from each islet chamber was collected in 1 min periods using fraction collectors; the insulin output rate was calculated as the product of the 
hormone concentration measured in the effluent and the perifusion flow rate. In about one-third of all perifusions, the insulin content of 40 islets of each species, set aside before perifusion, was measured after acid-ethanol extraction [15].

\section{Assay Procedures}

Insulin was measured by a charcoal separation method of radioimmunoassay [16]. Samples of perifusate and islet extracts from acomys were assayed using human insulin as standard, since no purified acomys insulin was available, and since serial dilutions of acomys samples reacted parallel to human (or porcine) but not to rat or mouse insulin standards. Samples from rats and the different mice tested were assayed using rat insulin as standard, since rat and mouse insulin provided identical standard curves. The immunoassay antibody used was guinea-pig anti-porcine insulin antiserum (kindly provided by Dr. P. H. Wright, Indiana University, Indianapolis, Ind.). Monocomponent porcine insulin was iodinated with $\left[{ }^{125} \mathrm{I}\right]$ (Eidg. Institut für Reaktorforschung, Würenlingen, Switzerland) by the chloramine-T method of Hunter and Greenwood [17] and purified on G 50 fine Sephadex (Pharmacia Fine Chemicals, Uppsala, Sweden). Purified crystalline insulins of the different species were kindly supplied by Dr. J. Schlichtkrull, Novo Research Institute, Bagsvaerd, Denmark.

Perifusate glucose was measured by a glucoseoxidase method [18], using reagents kindly donated by Dr. F. Schmidt, Boehringer-Mannheim GmbH, Germany.

\section{Results}

\section{Dose-Response Studies with Glucose}

As seen in Fig. 1, basal insulin release rates at the end of the initial 20 min perifusion with glucose 2.8 $\mathrm{mM}$ (i. e. $0 \mathrm{~min}$ on the abscissa) were low, stable and approximately the same for the islets from young acomys, albino mice, and rats. At 0 min the source of the perifusion medium was switched from the basic buffer reservoir containing glucose $2.8 \mathrm{mM}$ to that containing glucose $16.8 \mathrm{mM}$. The concentration of glucose in the effluent to the fraction collector started to increase at $1 \mathrm{~min}$, was $13 \mathrm{mM}$ at $2 \mathrm{~min}$, and reached $16.8 \mathrm{mM}$ at $3 \mathrm{~min}$. The rate of insulin release was first significantly increased at $2 \mathrm{~min}$ for rat islets $(P<$ $0.01)$, at $3 \mathrm{~min}$ for albino mouse islets $(P<0.01)$, and at $5 \mathrm{~min}$ for acomys islets $(P<0.05)$, i.e. not until 2
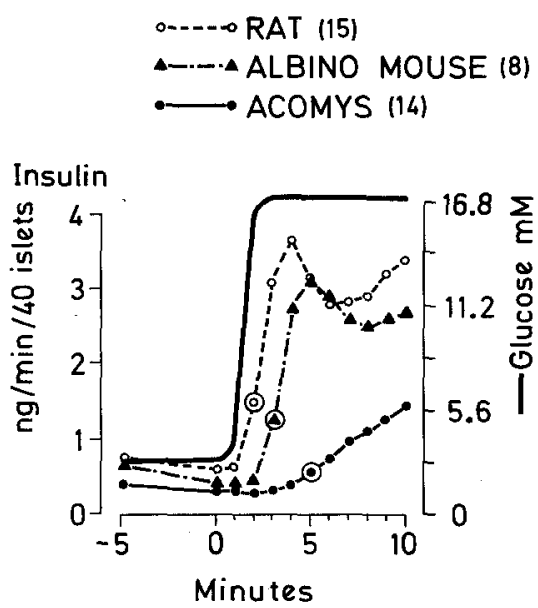

Fig. 1. Mean insulin release rates of isolated islets from rat $(\mathrm{n}=15$ expts), albino mouse ( $n=8$ expts), and acomys $(n=14$ expts) related to mean glucose concentration (the solid line) in the effluent from the islet chambers during the first $10 \mathrm{~min}$ after changing the perifusion buffer from glucose 2.8 to $16.8 \mathrm{mM}$. For $20 \mathrm{~min}$ prior to 0 time all islets were perifused with glucose $2.8 \mathrm{mM}$. The encircled value on each profile indicates the first rate of insulin release that is significantly increased above basal for the species concerned

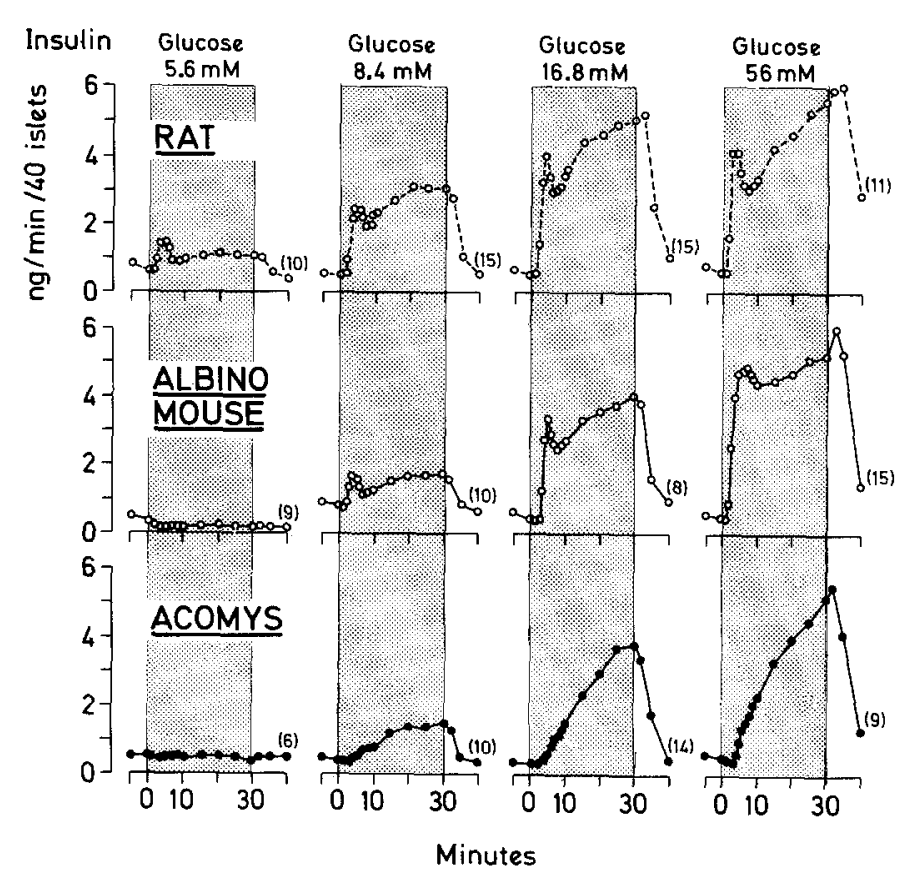

Fig. 2. Mean insulin release rates of islets from rat, albino mouse, and acomys perifused with glucose $2.8 \mathrm{mM}$ for $20 \mathrm{~min}$ (only last 5 min shown) followed by an increase in the perifusion medium glucose concentration to $5.6,8.4,16.8$ or $56 \mathrm{mM}$ for $30 \mathrm{~min}$, finally a return of medium glucose to $2.8 \mathrm{mM}$ for $10 \mathrm{~min}$. The numbers of experiments are indicated in brackets 
min after the glucose concentration had reached 16.8 $\mathrm{mM}$.

Fig. 2 illustrates differences in the patterns of insulin release from islets of the three species perifused over a range of glucose concentrations extending from 5.6 to $56 \mathrm{mM}$. With the exception of $5.6 \mathrm{mM}$ glucose applied to albino mice islets, glucose-induced insulin responses from islets of rats and albino mice exhibited a clear biphasic profile; the early (rapid) peak in the rate of release was usually seen at 4 min for rat islets and at $5 \mathrm{~min}$ for albino mouse islets, and was followed by a transient decrease with a nadir at about $7 \mathrm{~min}$ in both these control species; the secondary increase in insulin release then occurred but tended to flatten toward a plateau between 15 and 30 min after first increasing glucose in the perifusion medium. In clear contrast, acomys ( 8 to 14 weeks of age) islets appeared to lack the early phase of rapid insulin release almost completely, whereas the late phase was successively augmented with higher glucose concentrations, reaching levels not too different from those of the islets of mice or rats. When perifusion glucose was returned to $2.8 \mathrm{mM}$ from $30 \mathrm{~min}$ on, however, insulin release rates decreased equally promptly for the islets of all three species. It therefore appears unlikely that the early delay of insulin response to glucose in acomys islets had resulted from slowed outward diffusion of insulin released into the extracellular space within islets. Slight delays in the decrease of insulin release, upon returning from very high glucose concentration to glucose $2.8 \mathrm{mM}$, were noted for the islets of all three species, and have been reported elsewhere to result from abrupt decrease in medium osmolarity [19].

Fig. 3 characterizes the glucose dose-response relation for insulin release rates achieved either early (4 $\mathrm{min}$ ) or late (30 $\mathrm{min}$ ) after raising the concentration of glucose. The "threshold" for the early insulin response was glucose $5.6 \mathrm{mM}$ for rat islets $(P<0.01$ vs. basal release), and glucose $8.4 \mathrm{mM}$ for albino mouse islets $(P<0.01)$, whereas, even with glucose $56 \mathrm{mM}$, there was no significant early insulin response from acomys islets. By contrast to the flat dose-response curve for acomys islets at $4 \mathrm{~min}$, the sensitivity of acomys islets to glucose closely approximated that of albino mouse islets, at $30 \mathrm{~min}$. On the other hand, both acomys and albino mouse islets remained somewhat less sensitive to glucose than rat islets after $30 \mathrm{~min}$, half-maximal insulin response after $30 \mathrm{~min}$ occurring at glucose levels of approximately $8 \mathrm{mM}$ for rat islets, and $12 \mathrm{mM}$ for acomys and albino mouse islets. Similar maximal rates of insulin release were observed for all three rodents at $30 \mathrm{~min}$.
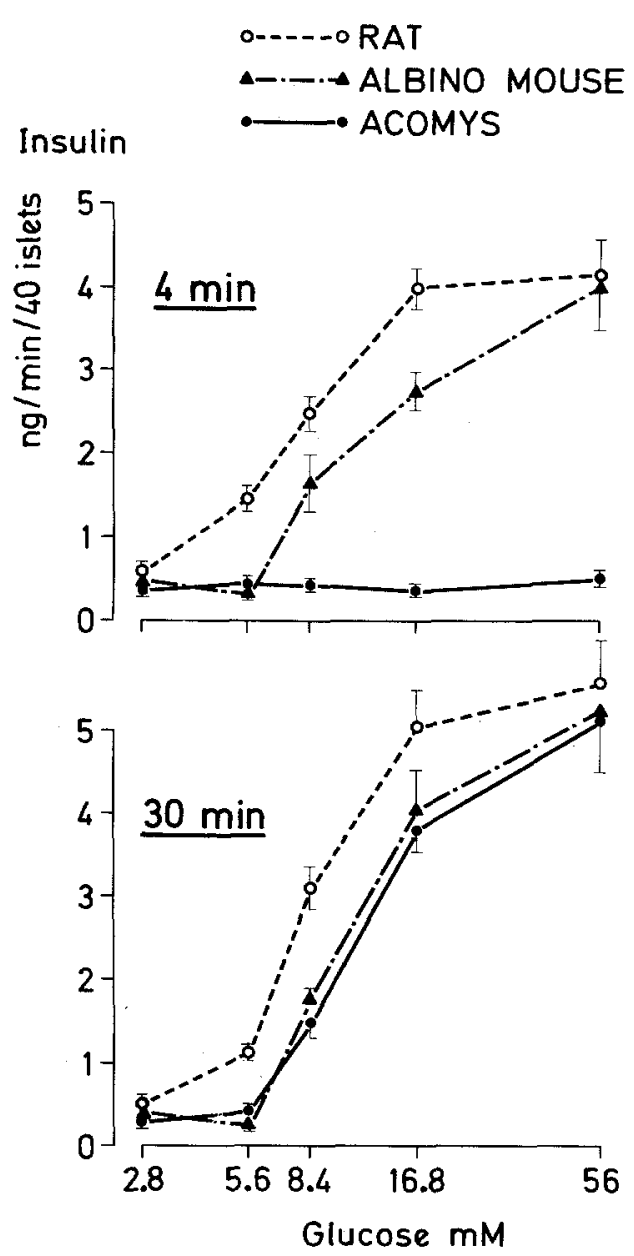

Fig. 3. Dose-response relation between glucose concentration (abscissa, logarithmic) and insulin release response (ordinate) utilizing the data obtained in the experiments described in Fig. 2. The relation is shown at both the 4 th and the 30 th min after switching to the stimulating glucose concentration

\section{Effects of Ageing and Obesity in Acomys}

The curves at the left of Fig. 4 show that the insulin response to glucose $16.8 \mathrm{mM}$ was biphasic for islets of both lean and obese $(o b / o b) \mathrm{C} 57 \mathrm{BL} / 6 \mathrm{~J}$ mice, whereas no early phase of rapid insulin release was observed either with islets of young acomys ( 8 to 14 weeks, 25 to $40 \mathrm{~g}$ ) - these summarizing data being pooled from those in Figs. 1 and 2 - or with islets of older, more obese acomys ( 22 to 36 weeks, 60 to $90 \mathrm{~g}$ ). The magnitude of the insulin response over the entire 30 min stimulation period with glucose $16.8 \mathrm{mM}$ appeared roughly proportional to the insulin content of the corresponding islets, represented by the columns to the right of Fig. 4 . Thus, a low early phase of insulin 


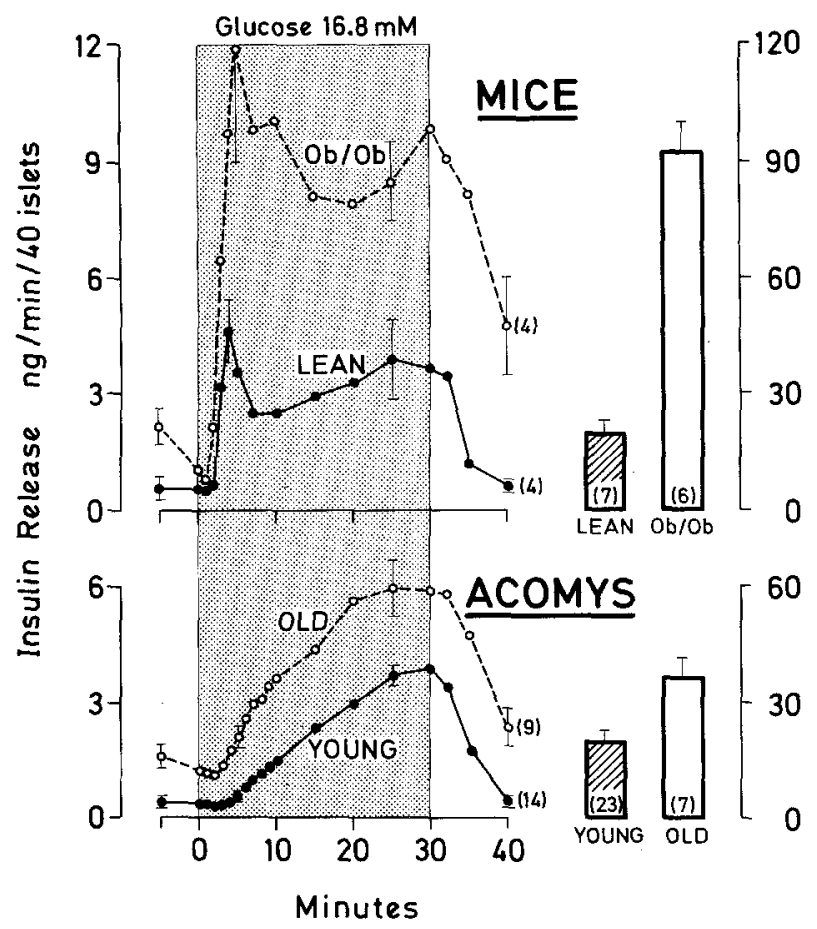

Fig. 4. Mean ( \pm SEM) insulin release rates (left panels); and islet insulin contents (on the right) for lean, and obese (ob/ob) $\mathrm{C} 57$ $\mathrm{BL} / 6 \mathrm{~J}$ mice (upper panels); and of young (8-14 weeks), and older (24-42 weeks) and more obese acomys (lower panels). The numbers of experiments or estimations are indicated in brackets release was a constant feature in the acomys population, present also in older and relatively obese animals.

\section{Effects of Other Insulin Secretagogues}

Table 2 compares, in islets from acomys ( 8 to 14 weeks) and rats, the effects of theophylline, cyclic AMP, arginine, tolbutamide and cytochalasin B on total insulin release during 30 min of perifusion with these agents, at three different glucose concentrations. With glucose $2.8 \mathrm{mM}$, a substimulatory glucose concentration in both species, theophylline $10 \mathrm{mM}$ resulted in a $91 \%$ increase in insulin release from rat islets $(P<0.02)$; arginine $16 \mathrm{mM}$ in a $138 \%$ increase $(P<0.005)$; and tolbutamide $1.5 \mathrm{mM}$ in a $169 \%$ increase $(P<0.005)$. At the same low glucose concentrations, however, all three agents exerted no significant effects on insulin release from acomys islets, either total release (Table 2) or any part of the insulin release profile (Fig. 5). By contrast, in the presence of stimulatory concentrations of glucose ( 8.4 and $16.8 \mathrm{mM}$ ), all agents tested increased insulin release to the same or even to a greater extent in acomys than in rat islets (Table 2 and Fig. 6); however, none of these agents elicited an early peak in the rate of insulin release from acomys islets.

Table 2. Effects of agents on total insulin release from islets of acomys cahirinus and of rats perifused over 30 min at different glucose concentrations

\begin{tabular}{|c|c|c|c|c|c|c|c|}
\hline Additions & & \multicolumn{2}{|c|}{$2.8 \mathrm{mM}$ Glucose } & \multicolumn{2}{|c|}{$8.4 \mathrm{mM}$ Glucose } & \multicolumn{2}{|c|}{$16.8 \mathrm{mM}$ Glucose } \\
\hline & & Acomys & Rat & Acomys & Rat & Acomys & Rat \\
\hline \multirow{3}{*}{$\begin{array}{l}\text { Glucose }(G) \text { alone } \\
G+\text { theophylline } \\
10 \mathrm{mM}\end{array}$} & & $11.4 \pm 1.2^{\mathrm{a}}$ & $8.5 \pm 1.5$ & $23.1 \pm 2.7$ & $83.7 \pm 9.1$ & $64.0 \pm 5.1$ & $99.6 \pm 8.1$ \\
\hline & & $12.9 \pm 1.0$ & $16.2 \pm 0.8$ & $53.5 \pm 5.1$ & $116.7 \pm 6.0$ & $100.0 \pm 8.7$ & $125.3 \pm 18.6$ \\
\hline & $\mathrm{P}^{\mathrm{b}}$ & $\operatorname{NS}(6)^{c}$ & $<0.02(6)$ & $<0.01(6)$ & $<0.02(6)$ & $<0.01(8)$ & NS (8) \\
\hline \multirow{3}{*}{$\begin{array}{l}\text { G alone } \\
\mathrm{G}+\text { cyclic AMP } \\
10 \mathrm{mM}\end{array}$} & & $5.8 \pm 1.1$ & $11.5 \pm 3.5$ & & & $58.8 \pm 5.0$ & $113.0 \pm 9.4$ \\
\hline & & $4.3 \pm 0.8$ & $10.1 \pm 2.8$ & & & $111.9 \pm 4.0$ & $118.5 \pm 5.0$ \\
\hline & $\mathbf{P}$ & NS (4) & NS (4) & & & $<0.005(6)$ & NS (6) \\
\hline \multirow{3}{*}{$\begin{array}{l}\mathrm{G} \text { alone } \\
\mathrm{G}+\text { arginine } \\
16 \mathrm{mM}\end{array}$} & & $7.8 \pm 1.1$ & $14.0 \pm 2.8$ & $26.6 \pm 1.1$ & $103.2 \pm 9.1$ & $60.3 \pm 6.8$ & $91.3 \pm 11.8$ \\
\hline & & $8.7 \pm 2.1$ & $33.3 \pm 4.5$ & $47.2 \pm 5.0$ & $155.6 \pm 19.5$ & $98.5 \pm 10.4$ & $147.7 \pm 11.8$ \\
\hline & $\mathrm{P}$ & NS (6) & $<0.005(8)$ & $<0.01(6)$ & $<0.05(6)$ & $<0.01(6)$ & $<0.01(6)$ \\
\hline \multirow{3}{*}{$\begin{array}{l}\mathrm{G} \text { alone } \\
\mathrm{G}+\text { tolbutamide } \\
1.5 \mathrm{mM}\end{array}$} & & $9.0 \pm 1.3$ & $11.7 \pm 1.6$ & $20.5 \pm 6.4$ & $57.9 \pm 5.5$ & & \\
\hline & & $12.2 \pm 1.1$ & $31.5 \pm 3.4$ & $22.1 \pm 4.5$ & $55.3 \pm 4.6$ & & \\
\hline & $\mathrm{P}$ & NS (6) & $<0.005(6)$ & NS (6) & NS (6) & & \\
\hline \multirow{3}{*}{$\begin{array}{l}\text { G alone } \\
\mathrm{G}+\text { cytochalasin } \mathrm{B} \\
10 \mu \mathrm{g} / \mathrm{ml}\end{array}$} & & & & & & $63.5 \pm 4.6$ & $132.0 \pm 9.1$ \\
\hline & & & & & & $112.6 \pm 5.1$ & $256.1 \pm 15.7$ \\
\hline & $\mathrm{P}$ & & & & & $<0.005(4)$ & $<0.005(4)$ \\
\hline
\end{tabular}

a mean $( \pm$ SEM) insulin release (ng/40 islets) integrated over 30 min.

${ }^{b} p$ values compare insulin release in the presence and in the absence of each agent by Student's paired $t$ test. NS $=$ not significant.

$c$ numbers of paired experiments. 


\section{ACOMYS}

In
$\frac{n}{0}$
$\frac{n}{0}$
$\frac{0}{8}$
$\frac{5}{8}$
RAT
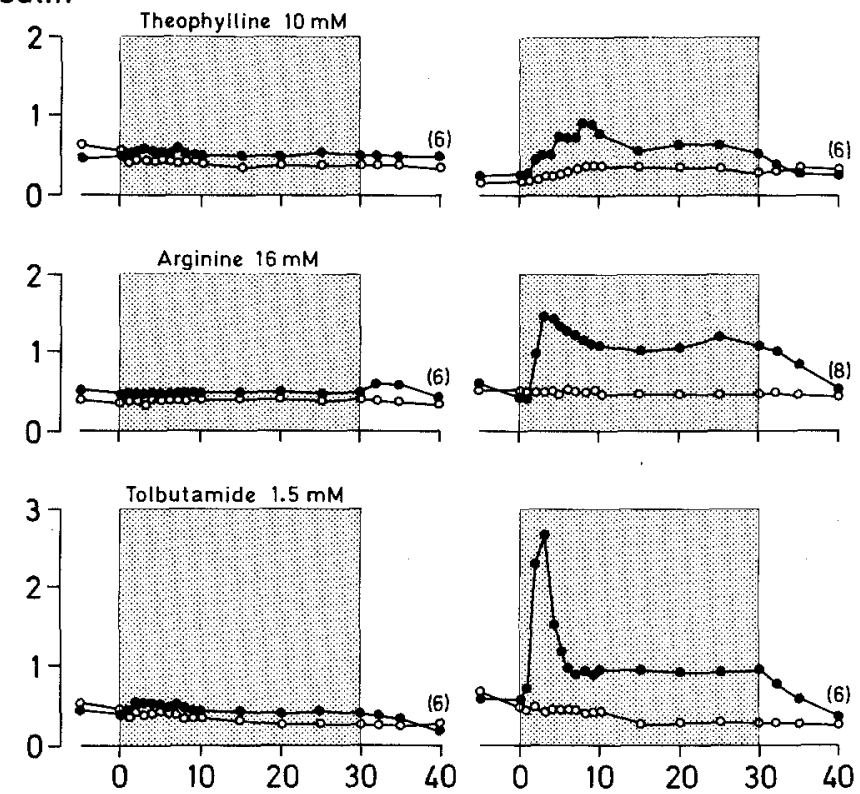

\section{0}

Minutes

Fig. 5. Mean insulin release rates from islets of acomys (left panels) and rat (right panels) perifused (during shaded periods) with glucose $2.8 \mathrm{mM}$ plus theophylline $10 \mathrm{mM}$, arginine $16 \mathrm{mM}$, or tolbutamide $1.5 \mathrm{mM}(\bullet-)$ ) and in paired control experiments with glucose $2.8 \mathrm{mM}$ alone $(0-0)$. Numbers of paired experiments are shown in brackets

\section{Discussion}

A sharp and early peak in the rate of insulin release followed by a transient decrease, then a slower rise, is a characteristic feature of the insulin response pattern to abrupt and sustained elevation of the glucose concentration, in man and in several animal species [20-22]. In the present study, similar biphasic insulin release responses to glucose have been observed in perifused islets isolated from normoglycemic rats, albino mice and $\mathrm{C} 57 \mathrm{BL} / 6 \mathrm{~J}$, lean mice, as well as from a mouse mutant, ob/ob $\mathrm{C} 57 / 6 \mathrm{~J}$ characterized by the tendency to develop obesity and hyperglycemia. By contrast, glucose-induced insulin release from islets of spiny mice, acomys cahirinus, was relatively delayed (Fig. 1), and no early peak insulin response was apparent, even when very high glucose concentrations were used (Fig. 2). This was true, whether the islets were obtained from young (8-14 weeks) or older and obese acomys (Fig. 4). The difference between the early response of acomys islets, and that of rat or mouse islets, could not be accounted for by differences in the insulin content of the islets of the three species, in the basal insulin release rates, or in the ease of
ACOMYS

RAT

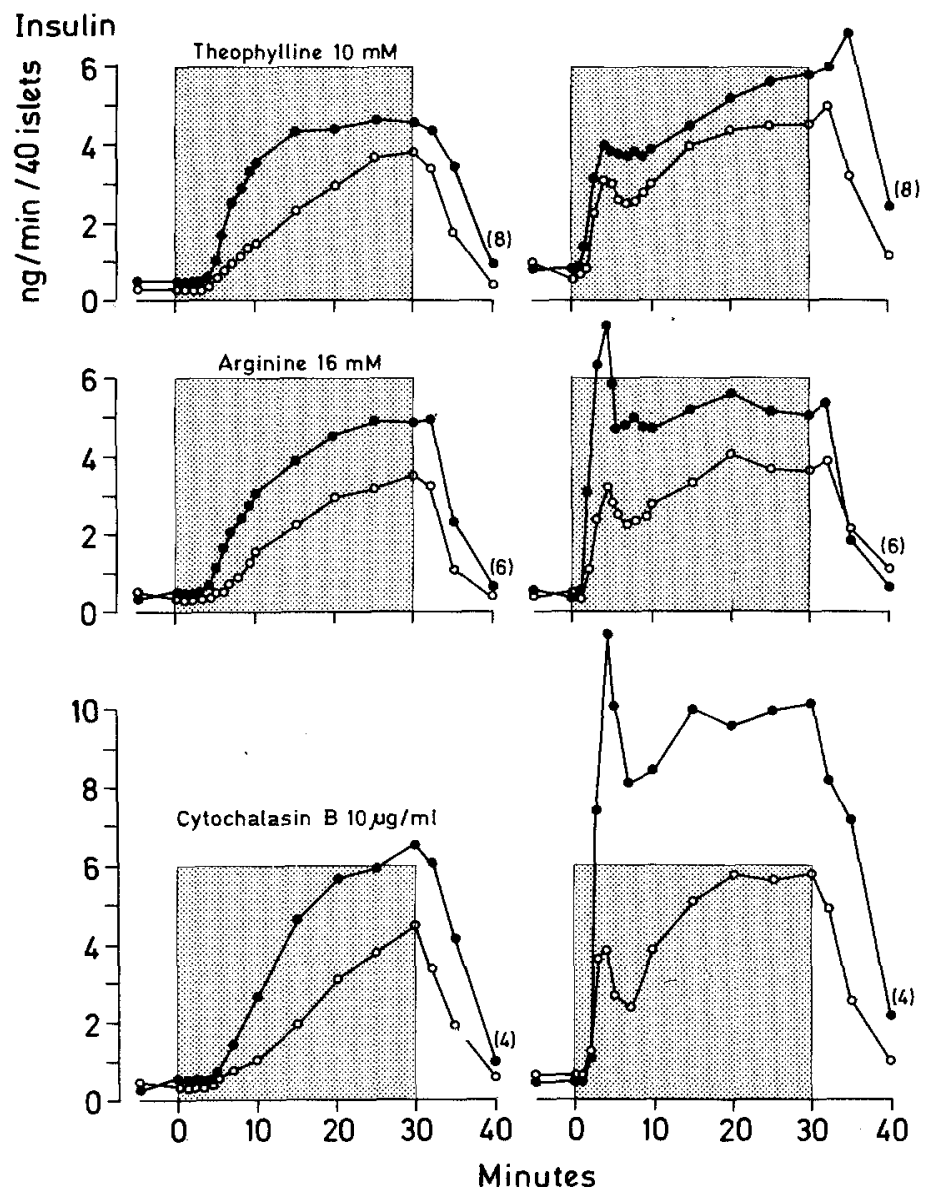

Fig. 6. Mean insulin release rates from islets of acomys (left panels) and rat (right panels) perifused (during shaded periods) with glucose $16.8 \mathrm{mM}$ plus theophylline $10 \mathrm{mM}$, arginine $16 \mathrm{mM}$, or cytochalasin B $10 \mu \mathrm{g} / \mathrm{ml},(\bullet-\bullet)$ and in paired control experiments with glucose 16.8 alone (o-o). For the experiments with cytochalasin, the agent was also present during the $20 \mathrm{~min}$ pre-stimulation period with glucose $2.8 \mathrm{mM}$, and control experiments with glucose $16.8 \mathrm{mM}$ alone were performed in the presence of dimethylsulfoxide $10 \mu \mathrm{L} / \mathrm{mL}$, the vehicle used to dissolve cytochalasin B. For SEMs and significance estimates of effectiveness of the agents used, see Table 2

diffusion of already released insulin from the extracellular space to the incubation medium.

Although studies in vivo [5] have demonstrated increases of plasma insulin as early as 2 min after intravenous injection of glucose in acomys, nevertheless, this early response was significantly less than that observed in control albino mice. Thus, the already small early response of the acomys B-cell in vivo may disappear entirely in vitro, perhaps as a result of further loss in sensitivity of acomys islets during isolation. Nevertheless, both in vivo [5] and in the present dynamic experiments in vitro, the differ- 
ences in insulin release between acomys and control rodents were greatest during the first few minutes of glucose stimulation, becoming progressively less with continued exposure to higher glucose concentrations. Indeed, after 15 to 30 min of constant glucose stimulation, the rate of insulin release from acomys islets had become similar to that from albino mouse islets, and approached that from rat islets. This time related difference is best seen when comparing the early and late dose response patterns shown in Fig. 3: whereas acomys islets were initially $(4 \mathrm{~min})$ insensitive to glucose (in concentrationsup to $56 \mathrm{mM}$ ), their sensitivity after $30 \mathrm{~min}$ exposure to stimulatory concentrations of glucose was identical to that of albino mice islets, although still less than that of rat islets, at all but the highest concentration of glucose $(56 \mathrm{mM})$. Thus, the insulin response of acomys islets could be clearly distinguished from that of both rat and albino mouse islets, by its early insensitivity to glucose. Fig. 3 also demonstrates a slightly lower sensitivity and higher threshold for glucose-induced insulin release for both acomys and albino mouse islets, when compared to rat islets. These findings may account for the higher plasma glucose levels observed in the acomys $(145 \pm 7$ $\mathrm{mg} / 100 \mathrm{ml})$ and albino mice $(157 \pm 16 \mathrm{mg} / 100 \mathrm{ml})$ than in the rats $(129 \pm 8 \mathrm{mg} / 100 \mathrm{ml})$ used in these experiments.

In order to determine whether the insensitivity of acomys islets was exclusive for glucose, several other insulin secretagogues were tested. Tolbutamide, arginine, theophylline, cyclic AMP and cytochalasin $B$ all failed to elicit an early spikelike insulin secretory response from acomys islets, whereas they did from rat islets, at least when associated with $16.8 \mathrm{mM}$ glucose. These findings in vitro are in agreement with those of Cameron et al. [4] in vivo, who reported that the intraperitoneal administration of glucose, arginine, glucagon, isoproterenol, aminophylline, and dibutyryl cyclic AMP caused either no early increases of plasma insulin in normoglycemic acomys, or increases very much smaller than in albino mice, or several mouse mutants. Thus the early secretory response for insulin would appear to be considerably less in acomys than in rats or mice, even when using a variety of agents presumably stimulating insulin secretion by different mechanisms, and whether stimulation is carried out in vivo or in vitro. This could be interpreted as suggesting a defect in the transport of insulin from a labile compartment, proposed as the source of initial insulin responses to a variety of agents [23].

Indeed, the recent demonstration by MalaisseLagae et al. [24] of a significant decrease in vincristine-induced paracrystalline deposits in acomys B-cells, by comparison to several other rodents, may suggest that the defect in acomys B-cells could be in the microtubular-microfilamentous system, which is involved in insulin secretion [25]. However, a symmetrical and only partial reduction of both phases of glucose-induced insulin release has been reported in rat islets after extensive disruption of the micro tubular apparatus by Vincristine [26]. Similarly, the apparently intact later phase of insulin release to glucose, as well as the intact potentiating action of other insulin secretagogues demonstrated in acomys islets in the present experiments, is difficult to explain on the basis of the apparently decreased microtubular content demonstrated in islets of this species.

Alternatively, the failure of theophylline, arginine and tolbutamide to stimulate insulin release from acomys islets in the presence of glucose $2.8 \mathrm{mM}$, by contrast to their effects on rat islets at the same glucose concentration (Fig. 5), could be the result of the higher threshold for glucose-induced insulin release in acomys islets (between 5.6 and $8.4 \mathrm{mM}$, Fig. 3) than in rat islets (between 2.8 and $5.6 \mathrm{mM}$, Fig. 3). Indeed, at glucose concentrations which were stimulatory in acomys islets $(8.4$ and $16.8 \mathrm{mM})$, all agents tested were as effective, occasionally more effective amplifiers of the glucose effect in acomys than in rat islets (Fig. 6 and Table 2). It therefore appears to us that the impaired early responses of acomys islets, to a variety of insulinogenic agents, may be based upon a more fundamental insensitivity to glucose.

The present experiments, however, do not permit further precise localization of the lesser sensitivity to glucose observed in acomys islets. This is hardly surprising since the mechanisms normally regulating biphasic insulin release are still far from understood [27]. Evidence for a common glucose receptor [28] or glucose mediated signal for both phases of insulin release is derived from the observations that in perfused rat pancreas [23], and in normal man [29], both phases of insulin release exhibit similar sensitivities to glucose. Also, both phases of insulin release have recently been reported to be impaired, and to a similar extent, in diabetic Chinese hamsters [30], although insulin responses were assessed at only a single glucose concentration. In the present study, sensitivities to glucose were also similar for the early (4 min) and late ( $30 \mathrm{~min}$ ) insulin responses in rat islets (half maximal stimulation occurring at about $8 \mathrm{mM}$ glucose, Fig. 3), while in albino mouse islets the corresponding concentration was $12 \mathrm{mM}$ for both phases. In acomys islets, however, sensitivity to glucose was considerably less in the early than in the 
late phase of insulin release, an observation which has also been reported in "prediabetic" human subjects [29]. Thus, regulation of early and late phases of insulin secretion may not necessarily be identical, at least not in all cases.

Although comparisons between acomys (or any animal) and man must remain guarded, nevertheless some understanding of the derangement of insulin secretion in diabetic man may be provided by examination of insulin secretion in the acomys, a species with the liability to develop spontaneous hyperglycemia and ketosis. Similar to our observations in the acomys, the early insulin response to glucose in prediabetic and diabetic human subjects has been shown by several investigators $[6-11,29]$ to be relatively more impaired than the late response. It has also been observed in man, that glucose, with time, may enhance markedly its own effect on insulin release, and that this "potentiating" action of glucose may be fully operative in subjects with low insulin responses [31]. It may be that such an action of glucose may account for the normal rates of insulin release observed in acomys islets after stimulation with elevated glucose concentrations for $30 \mathrm{~min}$. Furthermore, the enhancing effects of arginine [32, 33] and theophylline [34] on glucose-induced insulin release have been reported to be intact in subjects with decreased insulin responses, as demonstrated for acomys in the present experiments. Finally, it is proposed that the present findings in islets obtained from normoglycemic acomys may support the hypothesis that a basic defect in the diabetic islet, possibly preceding the occurrence of glucose intolerance, may involve some impairment in the recognition of glucose as an insulinogenic signal [29].

Acknowledgements. We are indebted to Mrs. Liza Cavillier for devoted and skilled technical assistance, to Mr. Raymond Cuche for expert care and help with the animals, and to Mr. Jean Mollard, for construction of the perifusion apparatus. This work was supported by grants 3.384.70 and 3.1060.73 of the Fonds National Suisse de la Recherche Scientifique, Bern, Switzerland, and by a grant-in-aid from the Fondation Education et Recherches, Basel, Switzerland.

\section{References}

1. Gonet, A. E., Stauffacher, W., Pictet, R., Mougin, J., Renold, A. E.: Obesity and diabetes mellitus with striking congenital hyperplasia of the islets of Langerhans in spiny mice (Acomys Cahirinus). Diabetologia 1, 162-171 (1965)

2. Stauffacher, W., Orci, L., Amherdt, M., Burr, I. M., Balant, L., Froesch, E. R., Renold, A. E.: Metabolic state, pancreatic insulin content and B-cell morphology of normoglycemic spiny mice (Acomys Cahirinus): indications for an impairment of insulin secretion. Diabetologia 6, 330-342 (1970)

3. Cameron, D., Stauffacher, W., Renold, A. E.: Spontaneous hyperglycemia and obesity in laboratory rodents. In: Handbook of Physiology. Section 7: Endocrinology (eds. D. F. Steiner and N. Freinkel) pp. 611-625. American Physiological Society, Washington, D. C. 1: Endocrine Pancreas 1972

4. Cameron, D. P., Stauffacher, W., Orci, L., Amherdt, M., Renold, A. E.: Defective immunoreactive insulin secretion in the acomys cahirinus. Diabetes 21, 1060-1071 (1972)

5. Gutzeit, A., Rabinovitch, A., Studer, P. P., Trueheart, P., Cerasi, E., Renold, A. E.: Decreased glucose tolerance and low plasma insulin responses in acomys cahirinus. Diabetologia $\mathbf{1 0}$, 667-70 (1974)

6. Perley, M. J., Kipnis, D. M.: Plasma insulin responses to glucose and tolbutamide of normal-weight and obese diabetic and nondiabetic subjects. Diabetes 15, 867-874 (1966)

7. Seltzer, G. S., Allen, E. W., Herron, Jr., A., Brennan, M. T.: Insulin secretion in response to glycemic stimulus: relation of delayed initial release to carbohydrate intolerance in mild diabetes. J. clin. Invest. 46, 323-335 (1967)

8. Cerasi, E., Luft, R.: Plasma insulin responses to glucose infusion in healthy subjects and in diabetes mellitus. Acta endocr. (Kbh.) 55, 278-304 (1967)

9. Soeldner, J. S., Gleason, R. E., Williams, R. F., Garcia, M. J., Beardwood, D. M., Marble, A.: Diminished serum insulin response to glucose in genetic prediabetic males with normal glucose tolerance. Diabetes 17, 17-26 (1968)

10. Simpson, R. G., Benedetti, A., Grodsky, G. M., Karam, J. H., Forsham, P. H. Early phase of insulin release. Diabetes 17, 684-692 (1968)

11. Blackard, W. G., Nelson, N. C.: Portal vein insulin concentrations in diabetic subjects. Diabetes 20, 286-288 (1971)

12. Cameron, D. P., Stauffacher, W., Amherdt, M., Orci, L., Renold, A. E. Kinetics of immunoreactive insulin release in obese hyperglycemic laboratory rodents. Endocrinology $\mathbf{9 2}$, 257-264 (1973)

13. Lacy, P. E., Kostianovsky, M.: Method for the isolation of intact islets of Langerhans from the rat pancreas. Diabetes 16, 35-39 (1967)

14. Kikuchi, M., Rabinovitch, A., Blackard, W. G., Renold, A. E.: Perifusion of pancreas fragments: A system for the study of dynamic aspects of insulin secretion. Diabetes 23, 550-559 (1974)

15. Scott, D. A., Fisher, A. M.: The insulin and zinc content of normal and diabetic pancreas. J. clin. Invest. 17, 725-728 (1938)

16. Herbert, V., Lau, K.-S., Gottlieb, C. W., Bleicher, S. J.: Coated charcoal immunoassay of insulin. J. clin. Endocr. 25, 1375-1384 (1965)

17. Hunter, W. M., Greenwood, F. C.: Preparation of iodine-131 labelled human growth hormone of high specific activity. Nature (Lond.) 194, 495-496 (1962)

18. Bergmeyer, H. U., Bernt, E.: D-Glucose-Bestimmung mit Glukose-Oxydase and Reoxydase. In: Methoden der enzymatischen Analyse (Bergmeyer, ed.) pp. 1172-1179. Verlag Chemie Weinheim 1970

19. Rabinovitch, A., Kikuchi, M., Gutzeit, A., Blackard, W. G., Renold, A. E.: Hyposmolarity as a cause of insulin and glucagon "off-responses" in vitro. Horm. Metab. Res. Suppl. 5, (1974)

20. Grodsky, G. M., Bennett, L. L., Smith, D., Nemechek, K.: The effect of tolbutamide and glucose on the timed release of insulin from the isolated perfused pancreas. In: Tolbutamide after Ten Years (eds. W. J. H. Butterfield, W. Van Westering) Excerpta med. Intern. Congr. Ser. (Amst.) 149, 11-21 (1967)

21. Kanazawa, Y., Kuzuya, T., Ide, T., Kosaka, T.: Plasma insulin responses to glucose in femoral, hepatic and pancreatic veins in dogs. Amer. J. Physiol. 211, 442-448 (1966)

22. Blackard, W. G., Nelson, N. C.: Portal and peripheral vein 
immunoreactive insulin concentrations before and after glucose infusion. Diabetes 19, 302-306 (1970)

23. Grodsky, G. M.: A threshold distribution hypothesis for packet storage of insulin and its mathematical modeling. J. clin. Invest. 51, 2047-2059 (1972)

24. Malaisse-Lagae, F., Ravazzola, M., Amherdt, M., Gutzeit, A., Malaisse, W. J., Orci, L.: An apparent abnormality of the B-cell microtubular system in spiny mice (Acomys cahirinus) Diabetologia 10, 71-76 (1975)

25. Malaisse, W. J., Malaisse-Lagae, F., Walker, M. O., Lacy, P. E.: The stimulus secretion coupling of glucose-induced insulin release. $V$. The participation of a microtubular-microfilamentous system. Diabetes 20, 257-265 (1971)

26. Devis, G., Van Obberghen, E., Somers, G., Malaisse-Lagae, F, Orci, L., Malaisse, W. J.: Dynamics of insulin release and microtubular-microfilamentous system. II. Effect of Vincristine. Diabetologia 10, 53-59 (1974)

27. Renold, A. E.: Insulin biosynthesis and secretion - a still unsettled topic. New Engl. J. Med. 282, 173-182 (1970)

28. Matschinsky, F. M., Ellerman, J. E., Krzanowski, J., KotlerBrajtburg, J., Landgraft, R., Fental, R.: The dual function of glucose in islets of Langerhans. J. biol. Chem. 246, 1007-1011 (1974)

29. Cerasi, E., Luft, R., Efendic, S.: Decreased sensitivity of the pancreatic beta cells to glucose in prediabetic and diabetic subjects. A dose-response study. Diabetes 21, 224-234 (1972).
30. Frankel, B. J., Gerich, J. E., Hagura, R., Fanska, R. E., Gerritsen, G. C., Grodsky, G. M.: Abnormal secretion of insulin and glucagon by the in vitro perfused pancreas of the genetically diabetic Chinese hamster. J. clin. Invest. 53, 1637-1646 (1974)

31. Cerasi, E.: Potentiation of insulin release by glucose in man. III. Normal recognition of glucose as a potentiator in subjects with low insulin response and in mild diabetics. Acta endocr. (Kbh.) 79, 511-534 (1975)

32. Floyd, J. C., Jr., Fajans, S. S., Conn, J. W., Triffault, C., Knopf, R. F., Guntsche, E.: Secretion of insulin induced by amino acids and glucose in diabetes mellitus. J. clin. Endocr. 28, 266-276 (1968)

33. Efendic, S., Cerasi, E., Luft, R.: Quantitative study on the potentiating effect of arginine on glucose-induced insulin response in healthy, prediabetic, and diabetic subjects. Diabetes 23, 161-171 (1974)

34. Cerasi, E., Luft, R.: The effect of an adenosine $3^{\prime}$, $5^{\prime}$-monophosphate diesterase inhibitor (Aminophylline) on the insulin response to glucose infusion in prediabetic and diabetic subjects. Horm. Metab. Res. 1, 162-168 (1969)
A. Rabinovitch, M. D.
Institut de Biochimie Clinique
Sentier de la Roseraie
$\mathrm{CH}-1211$ Genève 4
Switzerland 